\title{
The Effect of Transformational Leadership and Work Motivation on Teacher Performance Through Teacher Discipline
}

\author{
Dina Marlina *, Ahmad Suriansyah, Metroyadi \\ Master Program of Education Management, Universitas Lambung Mangkurat, Banjarmasin 70123, \\ Indonesia
}

Article history:

Submission November 2019

Revised June 2020

Accepted June 2020

${ }^{*}$ Corresponding author:

E-mail: dinamarrrlina@gmail.com

\begin{abstract}
This research describes the transformational leadership behavior, work motivation, teacher performance, and work discipline. It also considers the effect of transformational leadership behavior on work motivation; on work discipline; and teacher performance; effect of work motivation on teacher performance; the effect of work discipline on teacher performance; the effect of transformational leadership on teacher performance through work motivation; as well as the effect of transformational leadership on teacher performance through work discipline. The research uses a quantitative approach with descriptive methods involving a research sample of 105 people. The questionnaire was used as a data collection instrument, while hypotheses were tested using path analysis. Based on the results of the research, there is; a direct effect of transformational leadership on work motivation, work discipline, and teacher performance; a direct effect of work motivation on teacher performance; an indirect effect of transformational leadership on teacher performance through work motivation; as well as an indirect effect of transformational leadership on teacher performance through work discipline. Recommendations are made for teachers to improve performance during the teaching and learning processes, while there is a need for principals to optimize their coaching methods of teachers through improved transformational leadership.
\end{abstract}

Keywords: Transformational leadership, work motivation, work discipline, teacher performance

\section{Introduction}

Education is an important and inseparable part of human existence. In every nation, there are grounds and objectives peculiar to different generations as regards their educational needs. Consequently, concerted efforts are required in developing human resources of high quality who are prepared to become future leaders of various nations (Fattah, 2013). According to Fattah (2013), the environment is one of the factors that influence the birth of innovations which impacts the behavior, thoughts, as well as attitude of people. Education should not only be considered as a tool for preparing people for a future life, but also a present one. One of the characteristics of quality education is the capacity to make a person grow mentally as well as become useful and beneficial to human existence. To achieve this goal, there is a need for a structured effort in the selection of lessons, approaches, and ways to harmoniously execute various teaching methods. This process could also be conducted within the family setting as well as in the social world.

Additionally, there is an interplay of several resources such as people, facilities, infrastructure, finance, technology, and information, in most academic institutions. Nonetheless, human resources are considered the most important when it comes to education. The development of quality human resources requires quality education. This will positively impact the building of a better nation as it concerns capacity-development in various fields such as 
science and technology. Good attitude and mentality can support the realization of national development targets (Fattah, 2013). How then do these institutions harness and develop the energy, talent, and enthusiasm available in human resources?

The current level in the quality of education neither fully meets the needs of the society nor caters to the development of science and technology as well as art. Consequently, superior institutions are needed, which would be characterized by the following: (1) Dynamic and independent school administrators who can communicate the vision of academic excellence to staff and students; (2) The vision, mission and strategy to achieve clearly defined goals; (3) Competent teaching staff who have the eagerness and drive to carry out their professional tasks in innovative ways; (4) Students who are active, passionate and hardworking, as major factors of their learning culture; as well as; (5) Communities and parents who actively support quality education (Kunandar, 2008).

According to Normianti et al. (2019), education has a quality, whose impact is measured by the standard of living as well as the cultural transformation of the nation. To build a generation of young smart people, with high character and moral values, as well as great personalities, the atmosphere and learning processes must have some element of fun and create challenges for the students to develop themselves based on their talents and natural abilities. On the other hand, teachers are the human resources instrumental to the teaching and learning processes, because without teachers there will be difficulty in understanding the importance of education.

Also, improving the quality of learning is one of the ways of improving overall education. Learning is a process of interactive communication between learning resources, teachers, and students. Interactive communication could be achieved either directly through face-to-face activities or indirectly (Hosnan, 2014). Therefore, to get a better quality of education, there is a need for innovation in the learning process to find or review the current learning system, thereby making it more effective and efficient (Shoimin, 2014).
Quality education is very dependent on productivity and changes in a teacher. Teachers are expected to have a performance that can provide and prove the hopes and wishes of all parties, especially the general public who have given the school and teacher confidence in fostering the growth and development of their students. Teacher performance in carrying out tasks is very influential in achieving good quality education, so teacher performance is an important condition for achieving success in the world of education.

\section{Teacher Performance}

Teacher performance is very key in academic institutions because overall performance is highly dependent on teachers' professionalism while carrying out their responsibilities. Teacher performance is very closely related to what is done in the classroom as these affect learning activities. It is all of the teacher's efforts at achieving an effective and efficient learning process. More so, a teacher will only be able to achieve a high performance from students depending on the management of the learning process. Results of research conducted by Sudjana (2002) show that $76.6 \%$ of student learning outcomes are influenced by teacher performance.

Also, Samsudin (2006), defined performance as the execution of a role by a person through the abilities; while, Nawawi (2005) defined performance as the result of a job carried out by someone which can be appraised by others directly or indirectly. On the other hand, Mulyasa (2004) defined the performance as the results of work/task or the achievement at a job.

According to Suriansyah (2014), performance is a person's real behavior and results achieved in carrying out the tasks, accompanied by the motive to act following the expectation borne by their skills, experience, and motivation. Teacher's performance relates to teaching or learning processes, the results of which is the passing of useful knowledge and technology to students in a bid to aid their mental development. In this case, the teacher performance would be considered a reflection of the students' results from national examinations 
which are the final evaluations of these students at a certain academic level (Syarwani et al., 2018).

\section{Transformational Leadership}

According to Purwanto (2016), complex educational work requires skilled people who have a good understanding of how to implement the goals and objectives of an academic institution, as well as the relationship between the aspects of one and the other. As a result, it is necessary to have a school administrator who meets these requirements.

Every human being has innate leadership ability since they at least lead himself; and every leader must be held accountable. Consequently, leadership becomes everyone's business. Based on the leadership theory, this ranks first, that is, leadership is the most important skill everyone should have to succeed in life. A school administrator's leadership style can determine the success or failure of teaching and learning in such a school. According to Hersey and Blanchard (2002), a person's leadership style is a variety of personalities that can be seen in the way they influence the activities of others as interpreted by them. Leadership is said to focus on what is done by leaders since it is the process by which leaders explain an organization's goals to the people they lead.

The research of Rivai (2004) suggests that the character of a leader is very important because it reflects what the leader does in influencing the followers to realize the vision. Therefore, leadership is the overall pattern of the actions of a leader, both visible and invisible to his subordinates. In other words, leadership is the style and strategy as a result of a consistent combination of philosophy, skills, traits, as well as attitude exhibited by a leader as they influence the performance of the subordinates.

Leithwood et al. (1999) stated that "Transformational leadership is sensitive to the development of shared vision, delegation and institutionalization of organizational culture necessary to the restructuring efforts in an academic institution". Mondiani (2012) also submitted that transformational leadership implies a person's skillfulness in inspiring and motivating his followers or subordinates to achieve greater results than previously conceptualized. Also, a school leader should have an open-door policy towards subordinates and the immediate school community, as a result, there would be an improvement in the quality of education. Furthermore, a leader should create enabling conditions for his subordinates to attain high performance and achieve good results.

\section{Work Motivation}

Another factor influencing teacher performance is work motivation. This is the ability to influence someone to do a job. In work psychology, work motivation has a positive influence on work morale. Motivation is one of the various methods utilized by superiors to make subordinates work hard and also work smartly. An understanding of its patterns helps managers interpret each employee's work attitude. Managers can motivate their employees in ways peculiar to each person according to their most dominant patterns.

Some subordinates work only after being motivated by superiors; these often need to be motivated. Therefore, any form of motivation arising from a source outside the person being motivated is called extrinsic motivation. On the other hand, some subordinates work simply based on motivation from within themselves. Such motivation arising from within oneself is called intrinsic motivation (Usman, 2016).

Work motivation is another factor that affects teacher performance. According to Aslamiah et al. (2019), work motivation is encouragement from within and outside of oneself, to do something measurable both internally and externally. Work motivation has an important role in improving professionalism among teachers. Due to the importance of teacher performance in the teaching and learning processes, a teacher is required to carry out his role adequately and this professional ability is developed by mastering teaching skills with much practice, thereby enabling them to carry out their instructing duties effectively. Though the professionalism of a teacher might often be seen as a contradiction, it must only be to improve teacher performance (Hakim, 2008). 


\section{Work Discipline}

Work discipline is a system of positive growth in employees which reflects in the actions of the person. Discipline is the process of training employees to control their emotions and be able to work optimally. Furthermore, whenever a disciplinary action achieves positive results, it has educational values as well as reverses negative attitude of previously undisciplined employees or subordinates in the hope of improving their efficiency at work and helping them socialize better in day-to-day interactions without the fear of future punishment for past behavior (Rowen, 2017).

Therefore, a teacher should be of the utmost discipline. Teachers who are disciplined educate, teach, train their students as well as carry out their other duties as expected. The general decline in the enthusiasm of teachers is characterized by a lack of motivation and taking up less responsibility while carrying out a task (Sundari et al. 2019). Wetson (2008) stated that the standard of school administration is still very low as some principals shy away from taking responsibility for the academic performance in their schools. However, the situation is different at schools with high academic achievement, where the principals successfully play the roles of leaders and managers. Hoy and Miskel (2013) stated that a school's leadership has a very huge effect on the attitude and behavior of teachers, as well as the overall performance of the school. Gray (1990) also stated that there is no evidence to suggest that successful schools were managed by weak leaders.

Besides, according to Usman et al. (2007), as many as $19 \%$ of teachers in Indonesia absent themselves from work with no particular reason. Since teacher discipline has a major effect on the effectiveness and efficiency of the learning process, there need to be deterrent measures towards teachers who are not disciplined in the profession. This study aims to describe and analyze: (1) Transformational leadership behavior, work motivation, teacher performance, and teacher work discipline; (2) The effect of transformational leadership behavior on work motivation (3) The effect of transformational leadership behavior on work discipline; (4) The effect of transformational leadership behavior on teacher performance; (5) The effect of work motivation on teacher performance; (6) The effect of work discipline behavior on teacher performance; (7) The effect of transformational leadership on teacher performance through work motivation; (8) The effect of transformational leadership on teacher performance through work discipline.

\section{Material and Methods}

This research uses a quantitative approach with descriptive methods. The research sample of 105 people. Data collection instruments are questionnaires that have met the validity and reliability test requirements. Data analysis to test hypotheses using path analysis. A five scale model questionnaire was used for data-collection while validity, as well as reliability, were tested by choosing between one of five answers according to the actual conditions. There were four questionnaire points used in this research such as transformational leadership, work motivation, work discipline as well as teacher performance.

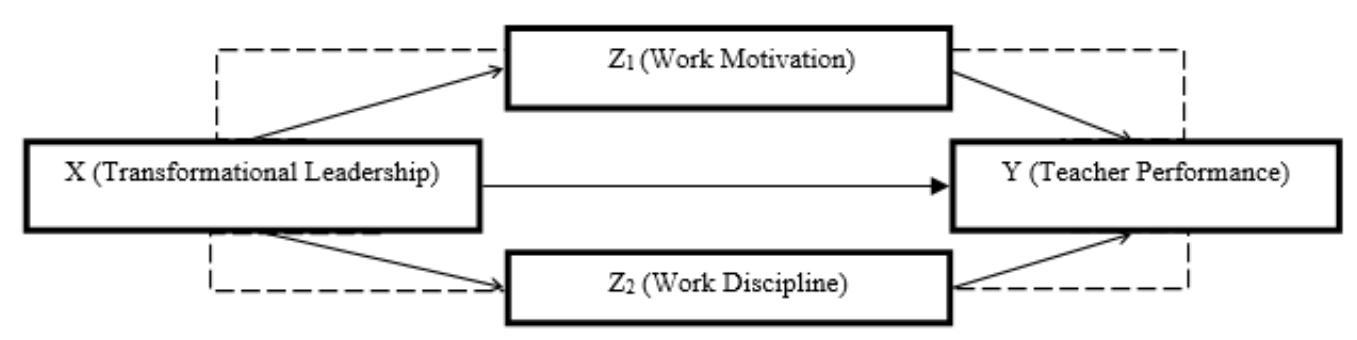

Figure 1. Conceptual effect model between variables

In reference to figure 1 above, the conceptual model uses path analysis to prove the seven research hypotheses which are namely
$\mathrm{H}_{1}$ : There is a direct effect of the transformational leadership of a principal on the work motivation of state junior high school teachers in 
Barabai District; $\mathrm{H}_{2}$ : There is a direct effect of a principal's transformational leadership on the work discipline of teachers of state junior high schools in Barabai District; $\mathrm{H}_{3}$ : There is a direct effect of a principal's transformational leadership on the performance of teachers of state junior high schools in Barabai district; $\mathrm{H}_{4}$ : There is a direct effect of work motivation on the performance of teachers of State Junior High Schools in Barabai District; $\mathrm{H}_{5}$ : There is a direct effect of work discipline on the performance of teachers of State Junior High Schools in Barabai District; $\mathrm{H}_{6}$ : There is an indirect effect of the principal's transformational leadership on teacher performance through the work motivation of state junior high schools in Barabai District; and $\mathrm{H}_{7}$ : There is an indirect effect of the principal's transformational leadership on teacher performance through the discipline of state junior high school teachers in Barabai District.

\section{Results and Discussion}

The relationship between the principal's transformational leadership, work motivation, work discipline as well as the performance of the junior high school teachers observed in Barabai District is illustrated in the figure below:

Table 1. Regression analysis results in direct and indirect effects

\begin{tabular}{cccc}
\hline & \multicolumn{2}{c}{ Regression Test } & \\
\cline { 2 - 3 } Variable & Directly & Indirect & Information \\
\hline $\mathrm{X}-\mathrm{Z}_{1}$ & 0.332 & & Significant \\
\hline $\mathrm{X}-\mathrm{Z}_{2}$ & 0.330 & & Significant \\
\hline $\mathrm{X}-\mathrm{Y}$ & 0.265 & Significant \\
\hline $\mathrm{Z}_{1}-\mathrm{Y}$ & 0.276 & & Significant \\
\hline $\mathrm{Z}_{2}-\mathrm{Y}$ & 0.306 & & Significant \\
\hline $\mathrm{X}-\mathrm{Z}_{1}-\mathrm{Y}$ & - & \multirow{2}{*}{0.092} & Significant \\
\hline $\mathrm{X}-\mathrm{Z}_{2}-\mathrm{Y}$ & - & 0.101 & Significant \\
\hline
\end{tabular}

The effect of principal transformational leadership on the work motivation of junior high school teachers in Barabai Disctrict

Results from this research shows there is a direct effect of work motivation on teacher work discipline, as proven by the path coefficient value of 0.332 . Therefore, it can be concluded that there is a direct effect of work motivation on the work discipline of junior high school teachers in Barabai District. The results of this research are in line with the research conducted by Akuoko et al. (2012) which proved that work motivation can influence teacher work discipline as well as guide their behavior while putting into consideration the volume of workload.

The influence of transformational leadership on work motivation is the reason for the desire, sense of responsibility, confidence as well as the strong determination to achieve while persevering when carrying out tasks. Unfortunately, only a few teachers have this desire as most neither care nor are diligent in their work. Based on the feedback from respondents in this research, a conclusion can be made that work motivation affects the work discipline of teachers in junior high schools in Barabai District.

Also, similar results were achieved in the research by Aprianti (2016). Results of the research had the following conclusions: (1) There was an impact the school set-up had on the discipline of the teachers at the State Elementary Schools in North Banjarmasin District; (2) There was an impact of motivation on the discipline of the teachers at the State Elementary Schools in North Banjarmasin District; and (3) There was an impact of the school set-up and motivation of outstanding teachers on the discipline of the teachers at the State Elementary Schools in North Banjarmasin District. 
The effect of principal transformational leadership on the work discipline of junior high school teachers in Barabai Disctrict

The results of this research show there is a direct effect of the principal's transformational leadership on teacher work discipline with a correlation of path coefficient value 0.330 . These results can, therefore, be interpreted that there is a direct effect of the principal transformational leadership on the work discipline of junior high school teachers in Barabai District. Similar research was also conducted by Nuryuniarti (2014). The calculation results show the tendency of respondents' scores for Variable X (Transformational Leadership) had an average of 3.79 while the $\mathrm{Y}$ Variable (Teacher Work Discipline) had an average score of 3.93. The magnitude of the effect of Variable $\mathrm{X}$ on variable $\mathrm{Y}$ is shown in the result of the determinant coefficient analysis as $38.07 \%$ while the remaining $61.03 \%$ is influenced by other factors. Based on the results, Y's regression equation on $\mathrm{X}$ proves there is a positive and significant influence between Transformational Leadership on the Discipline of Teacher Work in Bandung Vocational High School.

The effect of principal transformational leadership on the performance of junior high school teachers in Barabai Disctrict

Results from this research indicate there is a direct effect of transformational leadership on teacher performance. This can be seen from the path coefficient of 0.265 . These results can be interpreted to mean there is a direct effect between the transformational leadership of the principal on the performance of the teachers at Barabai District Middle School. The findings of the research conducted by Bubu (2016) are consistent with the results of this research which proves there is a relationship between transformational leadership and teacher performance with an R-value of 0.388 and a Sig value of 0.000 . Because the Sig number is smaller than 0.05 and probability is below 0.05 , then the correlation between transformational leadership and teacher performance is real.

Dharma (2005) defined transformational leadership within an educational or school environment as the competence and behavior a person brings to a job that determines the job's performance. Leadership is influence; it is the difference between what the leader determines to achieve and how s/he directs her/his subordinates in achieving it. One function of a leader is to maximize the potentials of teachers and faculty staff in achieving set school's goals. The principal should be able to apply the principles and methods of exemplary leadership in the motivation as well as the empowerment of all school staff. The role of a leader is huge, but with good leadership qualities, the principal is expected to influence teachers in improving their performance.

\section{The effect of work motivation on the perfor- mance of teacher of junior high school teach- ers in Barabai Disctrict}

The results of this research shows there is a direct effect of work motivation on teacher performance, as evidenced by the path coefficient value of 0.276 . Consequently, it can be concluded that there is a direct effect of the transformational leadership of a school principal on the performance of teachers in the Barabai District Junior High School. Similar results were achieved in the research by Ardiana (2017). The results show that work motivation had a positive effect on the performance of accounting teachers, contributing up to $80.6 \%$, while other factors outside the scope of the research contributed to the remaining $19.4 \%$.

Syamsudin et al. (2019) also had the same conclusion as follows: $\mathrm{H}_{4}$ : there is a direct relationship between work motivation and teacher performance at the state junior high schools in East Banjarmasin District, with a coefficient value of 0.020 . Work motivation has a great effect on a person's performance. A teacher will work optimally, exerting all abilities as well as skills when they have great work motivation. Work motivation is often clearly seen in the extent of involvement and participation at work.

The effect of work discipline on the performance of teachers of junior high school teachers in Barabai Disctrict

The results of this research prove there is a direct effect of work discipline on teacher performance, as evidenced by the path coefficient 
value of 0.306 . With this value, it can be concluded that there is a direct effect of work discipline on the performance of teachers in the Barabai District Junior High School. This position agrees with results of the research by Wulan (2013) which state the following: (1) There is a positive relationship between discipline and performance, with better discipline increasing teacher performance; (2) The principal, as manager and leader, has an important role in improving teacher performance; and (3) There are still teachers who lack discipline, and this negatively influences their work.

According to Madjid (2008), "If a teacher is accustomed to discipline in all things, then all his work will be completed properly and quickly. With work discipline, no teacher will neglect his responsibilities at work. Employee performance can be measured by the quality of work, level of honesty exhibited in every situation, an initiative taken, innovation or creativity when carrying out tasks, attitude towards work, cooperation with colleagues, reliability, knowledge of work, skillfulness, execution of responsibilities, as well as effective time utilization (Supardi, 2013).

The effect of principal transformational leadership on teacher performance through the work motivation of teacher of junior high school teachers in Barabai Disctrict

Consequently, there is an indirect effect of transformational leadership on teacher performance through work motivation, as proven by the product of path coefficients of the direct effect of variable $X$ on $Z_{2}$ (E3) and direct effect of the variable $Z_{2}$ on $Y$ (E5), that is, $0.332 \times 0.276$ $=0.092$. This means there is an indirect effect of the variable Transformational Leadership (X) on Teacher Performance (Y) through Work Motivation $\left(Z_{2}\right)$, with a factor of 0,092 . Furthermore, previous research conducted by (Rizal, 2019), has the following co has the following conclusions: (1) There is an effect of work motivation on the performance of junior high school teachers. Work motivation has a positive and significant effect on the performance of junior high school teachers by a factor of $46.4 \%$. (2) There is the effect of discipline on junior high school teacher performance. Discipline has a positive and significant effect on the performance of junior high school teachers by a factor of $21.4 \%$. (3) There is an effect of work motivation and discipline on the performance of junior high school teachers. Work motivation and discipline have a positive and significant effect on the performance of junior high school teachers by a factor of $50 \%$.

Improving teacher work motivation is an effort that requires a continuous drive from teachers in a bid to achieve success and progress. In this research, transformational leadership is dependent on two other factors namely, teacher performance and work motivation. The results prove transformational leadership influences teacher performance through work motivation. Motivation and good performance cannot be optimal if the leadership is not highly motivated.

\section{The effect of principal transformational leadership on teacher performance through the work discipline of middle school teachers in Barabai Disctrict}

The teacher is an important part of the education system; therefore, its performance requires the utmost attention. Teacher performance can be assessed through various indicators. Such indicators include the ability to plan, implement as well as provide learning assessments. Some of the factors that influence teacher performance are teacher work discipline and transformational leadership of school principals. Teacher performance, that is, achievement at work, is dependent on the teacher's ability to carry out tasks based on skill, experience, honesty as well as effective use of time during teaching. More so, teacher performance will only be good if the teacher displays loyalty, high commitment to responsibilities, high work discipline, creativity in teaching, collaboration with other school members, leadership qualities by becoming a role model to students, emotional intelligence and stability, honesty, as well as objectivity in guiding students.

Improvement in teacher work discipline is an effort that needs continual input from school 
principals who have authority over subordinates (teachers) to achieve success and progress. This should be supported by appropriate guidance and supervision from the school principals, as well as teachers' willingness to properly carry out their duties and responsibilities. Principal transformational leadership factor in this research is consistent with two other factors namely, teacher performance and work discipline, necessary for the achievement of overall success in schools. The results of this research prove the principal transformational leadership factor influences teacher performance through work discipline. Discipline and good performance cannot be optimal if the leaders at the school do not exemplify transformational leadership.

Nonetheless, results of this research indicate there is an indirect effect of the principal transformational leadership on teacher performance through work discipline, as evidenced by the product of the path coefficients of the direct effect of variable $X$ to $Z_{2}$ (E1) and direct effect of the $Z_{2}$ variable to $Y$ (E5), that is, $0.330 \mathrm{x}$ $0.306=0.101$. This means there is an indirect effect between the Transformational Leadership variable of Principal (X) on Teacher Performance $(\mathrm{Y})$ through Work Discipline $\left(\mathrm{Z}_{2}\right)$ to a factor of 0.101 .

A teacher will only be able to do well at teaching if supported by personal work discipline as well as the transformational leadership of the school principal. A teacher with high work discipline will be willing to carry out the task as an obligation.

\section{Conclusion and Recommendation}

The results found that there is a direct influence: (1) Transformational leadership on the work motivation of 0,332 ; (2) Transformational leadership on work discipline of 0,330 ; (3) Transformational leadership on teacher performance of 0,265 ; (4) Work motivation on teacher performance of 0,276 ; (5) Work discipline on teacher performance; and the indirect influence of 0,306: (6) Transformational leadership on teacher performance through work motivation of 0,092 ; (7) Transformational leadership on teacher performance through work discipline of 0,101 .
This study concludes that there is an influence of school principals' transformational leadership behavior and work motivation on teacher performance through the work discipline of Public Secondary School teachers in Barabai Subdistrict. It is recommended for teachers to always improve performance in schools in the teaching and learning process. For principals to be able to optimize coaching to teachers through transformational leadership.

\section{Acknowledgment}

The authors wish to grateful to the lecturers in the Master program of Education Management, who provided the much-needed input towards the success of this research. We also appreciate the reviewer and editor on the Education Horizon Journal team, for the opportunity to publish the results of this research. You all will receive the blessings of Allah SWT. Ameen.

\section{References}

Akuoko, K., Dounkor, \& Doris. (2012). Motivation and performance of teachers in slected second cycle institutions in the Ejitsu-Juaben Municipality, Ashanti Region, Ghana. International Journal of Business and Management ,2 (9), 1-10.

Aprianti, S. N. (2016). Kontribusi iklim organisasi dan motivasi kerja terhadap kedisiplinan guru SD negeri se-Kecamatan Banjarmasin Utara. Banjarmasin: Tesis: Universitas Lambung Mangkurat.

Ardiana, T. E. (2017). Pengaruh motivasi kerja guru terhadap kinerja guru akuntansi SMK di Kota Madiun. Universitas Muhammadiyah Ponorogo.

Aslamiah, Irawati, A., \& Saleh, M. (2019). Relationship between the principal role, motivation and satisfaction with the performance of elementary school teachers. Journal of $K 6$, Education, and Management (J-K6EM), 2(2), 87-96.

Bubu. (2016). Hubungan kepemimpinan transformasional dan disiplin kerja dengan kinerja guru Sekolah Dasar di Kecamatan Selat Kabupaten Kapuas. Banjarmasin. Tesis: Universitas Lambung Mangkurat.

Dharma, S. (2005). Manajemen kinerja falsafah teori dan penerapannya. Jakarta: Pustaka Pelajar.

Fattah, D. N. (2013). Landasan manajemen pendidikan. Bandung: PT. Remaja Rosdakarya.

Gray, J. (1990). The quality of schooling: Frame works for judgments. British Journal of Educational Leadership, 37, 15-27. 
Hakim, T. (2008). Belajar secara efektif. Jakarta: Pustaka Pembangunan Swadana Nusantara.

Hersey, P., \& Blanchard, K. (2002). Manajemen perilaku organisasi: Pendayagunaan sumber daya manusia edisi keempat. Penerjemah Agus Dharma. Jakarta: Erlangga.

Hosnan, M. (2014). Pendekatan saintifik dan kontekstual dalam pembelajaran abad 21. Bogor: Ghalia Indonesia.

Hoy, W., \& Miskel, C. (2013). Educational administration: Theory, research and practice. 7th edition. Newyork: McGraw-Hill.

Kunandar. (2008). Langkah mudah penelitian tindakan kelas sebagai pengembangan profesi guru. Jakarta: Raja Grafindo Persada.

Leithwood, K., Jantzi, D., \& Steinbach, R. (1999). Changing leadership for changing times. London: Open University Press.

Madjid. (2008). Mengangkat cerita dan martabat guru. Yogyakarta: Adicitra Karya Nusantara.

Mondiani, T. (2012). Pengaruh kepemimpinan transformasional dan kompensasi terhadap kinerja karyawan PT. PLN (PERSERO) UPJ. Semarang: Jurnal Administrasi Bisnis.

Mulyasa, E. (2004). Kurikulum berbasis kompetensi. Bandung: PT. Remaja Rosdakarya.

Nawawi, H. (2005). Penelitian terapan. Yogyakarta: Gadjah Mada University Press.

Normianti, H., Aslamiah, \& Suhaimi. (2019). Relationship of transformational leaders of principal, teacher motivation, teacher organization commitments with performance of primary school teachers in Labuan Amas Selatan, Indonesia. European Journal of Education Studies , 5: 124.

Nuryuniarti, G. (2014). Pengaruh kepemimpinan transformasional terhadap disiplin kerja guru di SMK Bina Warga Bandung. Thesis: Universitas Pendidikan Indonesia.

Purwanto, N. (2016). Administrasi dan supervisi pendidikan. Bandung: PT. Remaja Rosdakarya.

Rivai, V. (2004). Manajemen sumber daya manusia untuk perusahaan. Jakarta: PT. Raja Grafindo.

Rizal, A. S. (2019). Pengaruh motivasi kerja dan kedisiplinan terhadap kinerja guru SMP Kecamatan Bantarbolang. Program Studi Akuntansi: Universitas Pamulang.
Rowen. (2017). Pengaruh Disiplin Kerja dan Loyalitas Kerja terhadap Kinerja Karyawan CV. Tirta Agung Jaya Mandiri. Yogyakarta: Fakultas Ekonomi Universitas Sanata Dharma.

Samsudin, S. (2006). Manajemen sumber daya manusia. Bandung: Pustaka Setia.

Shoimin, A. (2014). 68 Model pembelajaran inovatif dalam kurikulum 2013. Yogyakarta: Ar-Ruzz Media.

Sudjana, N. (2002). Penilaian hasil proses belajar mengajar. Bandung: Remaja Rosdakarya.

Sundari, Aslamiah, \& Ngadimun. (2019). The influence of leadership, work llimate and spirit on elementary school teacher's discipline in Batu Ampar District Tanah Laut Regency. Journal of K6, Education, and Management (jK6EM) , 2(1), 78-86.

Supardi. (2013). KInerja guru. Jakarta: PT. Raja Grafindo Persada. Suriansyah, A. (2014). Hubungan budaya sekolah, komunikasi dan komitmen kerja terhadap kinerja guru sekolah dasar Negeri. Cakrawala Pendidikan , 3, 358-367.

Syamsudin, N., Wahyu, \& Suhaimi. (2019). Relationship principal leadership to work motivation, morale teacher and teacher performance of state junior high schools. Journal of K6, Education, and Management (J-K6EM) , 2(1), 15-22.

Syarwani, A., Saleh, M., \& Suhaimi. (2018). The influence of principal leadership style, organizational citizenship behavior, and work motivation on the performance of teachers of state vocational High School in Banjarmasin City. International Journal of Scientific Development and Research (IJSDR) , 3(12), 8-15.

Usman, H. (2016). Manajemen: Teori, praktik dan riset pendidikan. Jakarta: Bumi Aksara.

Usman, S., Akhmadi, \& Suryadharma, D. (2007). Pattern of teacher absence in public primary Schools in Indonesia. Asia Pacific Journal of Education , 27(2), 207-219.

Wetson, S. (2008). A study of junior secondary education in Indonesia: A review of the implementation of nine years universal basic education. USAID Indonesia: Academy of Educational Development.

Wulan, S. (2013). Hubungan disiplin dengan kinerja guru SMA Negeri di tiga Kecamatan Kota Depok. Jurnal Ilmiah WIDYA, 1(2),106-112. 